\title{
ANALISIS KEOPTIMALAN FUNGSI BAITUL MAAL PADA LEMBAGA KEUANGAN MIKRO ISLAM (STUDI KASUS PADA BMT NURUL JANNAH DI GRESIK DAN BMT MUDA DI SURABAYA)
}

\author{
Rana Ayu Azizah \\ Mahasiswa Program Studi S-1 Ekonomi Islam - Fakultas Ekonomi dan Bisnis - Universitas \\ Airlangga \\ Email: rana.ayu10@gmail.com \\ Noven Suprayogi \\ Departemen Ekonomi Syariah - Fakultas Ekonomi dan Bisnis - Universitas Airlangga \\ Email: noven.suprayogi@feb.unair.ac.id
}

\begin{abstract}
:
Basically Baitul Maal wa tamwil (BMT) have to run optimally both their business functions (Baitul tamwil) and social functions (Baitul Maal). Optimal can be seen from how the organization runs their operations effectively and efficiently. The aim of this research was to determine what causes of less-optimal from the social functions (Baitul Maal) on BMT.

This research used qualitative approach and case study method with explanatory study. The informants in this research were managers and administrators of BMT. Based on that method, the selected informants were executive manager of BMT, menager of Baitul Maal, and management of BMT. Data collected by interviews with informants using validation method of sources and data triangulation.

The results of this research indicate that their motivation cause disoptimal Baitul Maal function at Islamic microfinance institutions (case study at BMT Nurul Jannah Gresik and BMT Muda Surabaya).
\end{abstract}

\section{Keywords: Optimalization, Islamic Microfinance Institutions, BMT Functions}

\section{PENDAHULUAN}

\section{A. Latar Belakang}

Masyarakat dan ekonomi adalah salah satu kesatuan yang tidak dapat dipisahkan. Guna memenuhi kebutuhannya, manusia membutuhkan bantuan orang lain. Dalam kegiatan ini, ekonomi berperan untuk dapat memudahkan transaksi tersebut. Kegiatan ekonomi meliputi banyak hal seperti jual beli dan investasi. Jumlah masyarakat yang banyak ditambah dengan kemampuan masyarakat dalam konsumsi juga tinggi, memperbesar kesempatan lembaga-lembaga keuangan untuk mengembangkan potensinya.
Krisis yang pernah melanda
bangsa Indonesia serta rendahnya
kualitas SDM (Sumber Daya Manusia) juga
menjadi salah satu faktor penting dalam
jatunnya perekonomian. Sektor perekonomian menjadi landasan sebuah negara dalam menghadapi segala krisis yang ada sehingga ekonomi menjadi faktor penting dan penentu apakah sebuah negara tersebut dianggap maju atau tidak.

Perkembangan ekonomi syariah juga diikuti dengan lembaga keuangan bukan bank (LKBB) yang juga semakin banyak. Pada lembaga keuangan bank dikenal sebagai perbankan syariah, 
sedangkan pada lembaga keuangan bukan bank mengacu pada Pasal 49 huruf i Undang-undang Nomor 3 Tahun 2006 terdiri dari reksadana syariah, obligasi syariah dan surat berharga berjangka menengah syariah, lembaga kevangan mikro syariah, asuransi syariah, reasuransi syariah, pembiayaan syariah, sekuritas syariah, pegadaian syariah, dana pensiun lembaga keuangan syariah, dan bisnis syariah. Baitul Maal wa Tamwil (BMT) tercangkup dalam istilah lembaga keuangan mikro syariah.

Perkembangan BMT di Indonesia di mulai pada tahun 1984 yang diawali dengan dikembangkannya masjid Salman oleh mahasiswa ITB untuk mencoba menggulirkan lembaga pembiayaan berdasarkan syariah bagi usaha kecil yang dikenal dengan lembaga Teknoso, lembaga semacam BMT, yang kemudian bubar. Koperasi Ridho Gusti pada tahun 1988 juga menggunakan prinsip bagi hasil. Pada bulan juni 1992 beroperasi BMT Bina Insan Kamil di Jakarta ( Nanda, 2012: 12).

Baitul Maal wa Tamwil (BMT) memiliki fungsi sosial (Baitul Maal) dan fungsi bisnis (Baitul Tamwil) yang harus dilakukankan secara optimal. BMT menjalankan usahanya berada di bawah pembinaan Pusat Inkibasi bisnis Usaha Kecil (Pinbuk) dengan status legal berbentuk koperasi . BMT memiliki peran sebagai lembaga keuangan yang tidak hanya menjankan bisnis yang berbasis keuntungan (profit oriented) tetapi juga lembaga yang turut serta mengentaskan masyarakat dari kemiskinan. Usaha dalam membantu permasalahan tersebut juga termasuk salah satu produk penyaluran dana yang disebut Al-Qardhul Hasan.

Peran BMT dalam fungsi sosial ini yang membedakan lembaga keuangan BMT dengan yang lainnya. Pada lembaga keuangan lainnya, tidak ada keharusan yang terikat bahwa lembaga tersebut menjalankan fungsi sosial pada masyarakat sedangkan pada BMT, fungsi sosial dan fungsi bisnis harus berjalan bersamaan dan optimal.

Fakta empiris menyatakan banyak Baitul Maal wa Tamwil (BMT) yang menjalankan fungsi sosialnya dalam prosentase yang tidak sebesar untuk fungsi bisnisnya bahkan ada yang tidak menjalankan fungsi sosialnya. Tidak jarang Baitul Maal wa Tamwil (BMT) tidak menjalankan fungsi sosial seperti yang seharusnya. Fenomena tersebut tidak hanya terjadi pada satu BMT tetapi beberapa BMT juga tidak menjalankan fungsi baitul maalnya dengan optimal.

Penelitian ini bertujuan untuk mengetahui apa penyebab keoptimalan fungsi baitul maal pada lembaga keuangan mikro Islam studi kasus pada baitul maal wa tamwil (BMT). Subyek penelitian ini adalah BMT Nurul Jannah di Gresik dan BMT Muda di Surabaya. Berdasarkan uraian di atas maka rumusan masalah dari penelitian ini adalah: mengapa fungsi sosial (baitul maal) di baitul maal wa tamwil (BMT) kurang optimal? 
II. LANDASAN

TEORI

DAN

PENGEMBANGAN PROPOSISI

\section{A. Lembaga Keuangan Islam}

Menurut Rodhoni dan Hamid dalam Nanda (2012:17) tujuan berdirinya lembaga keuangan syariah adalah:

1. Mengembangkan lembaga keuangan syariah (bank dan non bank syariah) yang sehat berdasarkan efisiensi dan keadilan, serta mempu meningkatkan partisipasi masyarakat banyak sehingga menggalakkan usahausaha ekonomi rakyat dengan cara memperluas ke daerah-daerah terpencil.

2. Meningkatkan kualitas kehidupan sosial dan ekonomi masyarakat Indonesia, sehingga dapat mengurangi kesenjangan ekonomi yang akan melestarikan pembangunan nasional antara lain:

a. Meningkatkan kualitas dan kuantitas usaha.

b. Meningkatkan kesempatan kerja.

c. Meningkatkan penghasilan masyarakat banyak.

d. Meningkatkan partisipasi masyarakat banyak dalam poses pembangunan, terutama dalam bidang ekonomi keuangan yang banyak dari masyarakat yang masih enggan berhubungan dengan bank ataupun lembaga keuangan lainnya. e. Mendidik dan membimbing masyarakat untuk berfikir secara ekonomi, perilaku bisnis dan meningkatkan kualitas hidup mereka

\section{B. Baitul Maal Wa Tamwil (BMT)}

BMT mulai mengalami peningkatan signifikan padatahun 1995 yang ditamdai dengan didirikannya PINBUK (Pusat Inkubasi Bisnis Usaha Kecil) oleh ketua MUI (Majelis Ulama Indonesia), ketua ICMI (Ikatan Cendekiawan Muslim Indonesia) dan direktur utama Bank Muamalat Indonesia. PINBUK pada saat itu memperkenalkan dan mempopulerkan istilah BMT yang disertai dengan bantuan teknis dalam pengelolaan funsi BMT.

Baitul Maal wa Tamwil (BMT) terdiri dari dua istilah yaitu Baitut al-maal dan Baitut tamwil. Baitul maal lebih pada usaha-usaha pengumpulan dana non profit seperti zakat, infaq, dan shodaqoh. Sedangkan Baitul tamwil sebagai usaha pengumpulan dan penyaluran dana komersial. (Sudarsono, 2012:103). Dalam definisi operasional PINBUK, BMT adalah lembaga ekonomi rakyat kecil beranggotakan satu orang atau badan hukum berdasarkan prinsip syariah dan prinsip koperasi, yang diharapkan menjadi lembaga pendukung kegiatan ekonomi masyarakat kecil dengan berlandaskan prinsip syariah.

IImi (2002: 65) berpendapat bahwa baitul maal (rumah harta) merupakan lembaga kevangan yang berorientasi sosial keagamaan yang kegiatan utamanya adalah menampung dan 
menyalurkan zakat, infaq dan shodaqoh sesuai dengan peraturan yang ada di AlQuran dan Sunnah Rasul-Nya, sedangkan baitut tamwil (rumah pembiayaan) merupakan lembaga keuangan yang kegiatan utamanya menghimpun dana masyarakat dalam bentuk (simpanan) maupun deposito dan menyalurkan kembali kepada masyarakat dalam bentuk pembiayaan berdasarkan prinsip syariah melalui mekanisme yang lazim di dunia perbankan.

Baitul Maal Wa Tamwil (BMT) merupakan salah satu lembaga ekonomi dan keuangan yang dikenal luas pada masa-masa awal Islam berkembang. Baitul Maal yang berkembang pada masa-masa awal kejayaan Islam yang berfungsi sebagai institusi keuangan publik, yang oleh sebagian pengamat ekonomi disejajarkan dengan lembaga yang menjalankan fungsi perekonomian, bank sentral.

Baitul Maal Wa Tamwil merupakan lembaga keuangan yang memiliki fungsi sebagai lembaga intermediari yaitu lembaga yang menerima dana dari masyarakat yang memiliki harta berlebih yang akan dikelola dan diperuntukkan bagi masyarakat yang kekurangan modal. Sebagai lembaga keuangan mikro Islam, BMT bertujuan menjadi lembaga yang dapat memberi manfaat serta kesejahteraan tidak hanya pada anggota BMT tetapi masyarakat sekitar cakupan BMT untuk dapat hidup lebih baik sehingga kesenjangan sosial semakin menipis.
Fungsi lain dari BMT yang membedakannya dengan lembaga kevangan lainnya adalah penerimaan dana sosial dari Zakat, Infaq, sedekah dan Waqaf dari anggota ataupun masyarakat yang berlebih pada golongan masyarakat yang kekurangan. Fungsi sosial ini menjadikan BMT bukan hanya sebagai lembaga keuangan yang bergerak dalam sektor ekonomi melainkan pada sisi dakwah keagamaan bagi para nasabah pembiayaan. Tujuan dari fungsi ini untuk menjadikan masyarakat tidak hanya berfikir dunia saja tetapi juga dapat memberi manfaat kepada sesama manusia melalui zakat infaq dan shodaqoh.

\section{c. Motivasi}

Menurut Stephen P. Robbins (Wibowo, 2013:378) motivasi merupakan proses yang menimbulkan adanya intensitas (intensity), arah (direction), dan usaha terus-menerus (persistance) yang dilakukan oleh individu menuju pencapaian tujuan. Jerald Greenberg dan Robert A. Baron (Wibowo, 2013:379) berpendapat bahwa motivasi merupakan serangkaian proses yang membangkitkan (arouse), mengarahkan (direct), dan menjaga (maintain) perilaku manusia menuju pada pencapaian tujuan.

Adanya kebutuhan memunculkan manusia bekerja untuk dapat memenuhinya. Manusia bekerja untuk mencapai tujuan yaitu memenuhi kebutuhan pribadi ataupun kebutuhan organisasi. Manusia bekerja berharap untuk mendapat kompensasi nerupa 
upah, gaji, dan imbalan dari pekerjaan yang telah dilakukan. Seseorang yang telah muncul motivasinya untuk memenuhi kebutuhan pribadinya maka harus menjaga kinerja agar selalu lebih baik.

Menurut Rivai (2009:863), sumber motivasi ada tiga faktor, yaitu:

1. Kemungkinan untuk berkembang.

2. Jenis pekerjaan.

3. Apakah mereka dapat merasa bangga menjadi bagian dari perusahaan.

Motivasi merupakan salah satu faktor yang menggerakkan seseorang melalui proses psikologi untuk dapat melakukan aktivitas dalam rangka mencapai tujuan yang diharapkan, sedangkan motivasi bekerja merupakan faktor pendorong yang tumbuh dari diri seseorang untuk menggerakkan seseorang melakukan suatu pekerjaan dengan semua kemampuan yang dimiliki dengan tujuan mendapatkan hasil yang diinginkan.

Motivasi merupakan suatu energi di dalam diri seseorang yang mendorong, membangkitkan, mengarahkan, dan menjaga perilaku seseorang untuk dapat mencapai tujuan tertentu. Manusia sebagai hamba allah yang paling sempurna ditekankan untuk melakukan segala sesuatu dengan sebaik-baiknya dan berlomba-lomba dalam kebaikan.

\section{Fokus}

Literatur manajemen strategik menunjukkan pengelompokan hasil yang maksimal dalam analisis SWOT organisasi terhadap saingan mereka. Organisasi yang berhasil adalah mereka yang memiliki kompetensi khusus dan berkelanjutan dari waktu ke waktu. Prahalad dan Hamel (dalam Beekun, 2006:28) mendefinisan inti kompetensi sebagai pembelajaran bersama di dalam organisasi, terutama bagaimana cara mengkoordinasi bermacam-macam skill (kemampuan) produksi dan menggabungkan bermacam-macam kemajuan teknologi. Organisasi harus mengenali kompetensi yang mana yang harus difokuskan kemudian meninggalkan pekerjaan yang mana relatif lemah dan tidak efektif, dan yang tidak selaras dengan visi dan misi organisasi tersebut. Satu kunci di dalam proses ini adalah kemampuan untuk menghilangkan persaingan yang berkelanjutan dari persaingan yang ada sekarang dan di masa depan.

Islam juga melarang manusia untuk bersikap sombong terhadap apa yang telah dihasilkan dan meragukan serta merendahkan kontribusi Allah SWT. Berharap lebih terhadap kemampuan pemimpin dapat mejerumuskan organisasi mengingat sejarah Islam penuh dengan kematian dan akhir organisasi dari arogansi pemimpin serta tidak pernah melihat kemampuan organisasi selain organisasi sendiri (Beekun, 2006:29).

\section{E. Optimalisasi, Efisiensi, dan Efektivitas}

Menurut Kamus Besar Bahasa Indonesia (KBBI, 2001:705), optimalisasi adalah suatu proses, cara atau perbuatan untuk menjadikan sesuatu paling baik dan 
paling tinggi. Kata optimalisasi dapat dilihat memiliki dari kata dasar optimal. Untuk dapat mencapai hasil yang optimal maka perlu dilakukan proses pengoptimalan atau optimalisasi maksudnya adalah memberikan nilai optimal pada suatu hal. Dari pengertian tersebut dapat disimpulkan bahwa optimalisasi menunjukkan suatu proses atau kegiatan yang dilakukan untuk mencapai atau mendapatkan kondisi yang terbaik dan tertinggi.

Griffin (2011: 5-6) menyatakan bahwa efisien adalah menggunakan sumber daya secara bijaksana dan dengan cara yang hemat sedangkan efektif berarti membuat keputusan yang tepat dan berhasil menerapkannya.

Agoes (2013: 179), menyatakan bahwa efisiensi adalah bertindak untuk membuat pengorbanan yang paling tepat dibandingkan dengan hasil yang dikehendaki sedangkan efektivitas adalah perbandingan masukan-keluaran berbagai kegiatan, sampai dengan pencapaian tujuan yang ditetapkan, ditinjau dari kuantitas atau volume hasil kerja, kualitas hasil kerja, maupun batas waktu yang ditargetkan.

Menurut Agung (2005:109), dalam bukunya Transformasi Pelayanan Publik, mendefinisikan efektivitas sebagai kemampuan melaksanakan tugas, fungsi (operasi kegiatan program atau misi) daripada suatu organisasi atau sejenisnya yang tidak adanya tekanan atau ketegangan diantara pelaksanaannya.
Efektifitas adalah kemampuan untuk memilih tujuan yang tepat atau peralatan yang tepat untuk pencapaian tujuan yang telah ditetapkan, menyangkut bagaimana melakukan pekerjaan yang benar (Handoko, 2003:7).

Menurut Daft (2001:26) efektivitas adalah tingkat dimana organisasi mampu menyadari tujuannya. Efektivitas itu mengukur sejauh mana tujuan-tujuan yang ada di organisasi telah tercapai. Sedangkan efisiensi dalam pengertian sempitnya adalah menyinggung bagaimana internal organisasi dalam menjalankan tugasnya. Efisiensi dapat diukur dengan melihat input ataupun output dari organisasi. Jika dalam satu organisasi dapat mencapai produktifitas dengan menggunakan sumber daya yang lebih sedikit dari pada yang dihasilkan maka organisasi tersebut dikatakan efisien.

Dari pengertian mengenai optimalisasi, efisiensi, dan efektivitas tersebut di atas, maka dapat dipahami bahwa terdapat hubungan yang kuat di antara ketiga dimensi tersebut. Setiap organisasi pasti memiliki tujuan atau sasaran yaitu sebuah kondisi terbaik atau tertinggi yang ingin dicapainya. Dari sinilah terdapat serangkaian kegiatan manajemen (aktivitas manajerial) yang butuhkan oleh organisasi agar dapat mencapai goals atau sasaran tersebut. 
F. Kerangka Berfikir

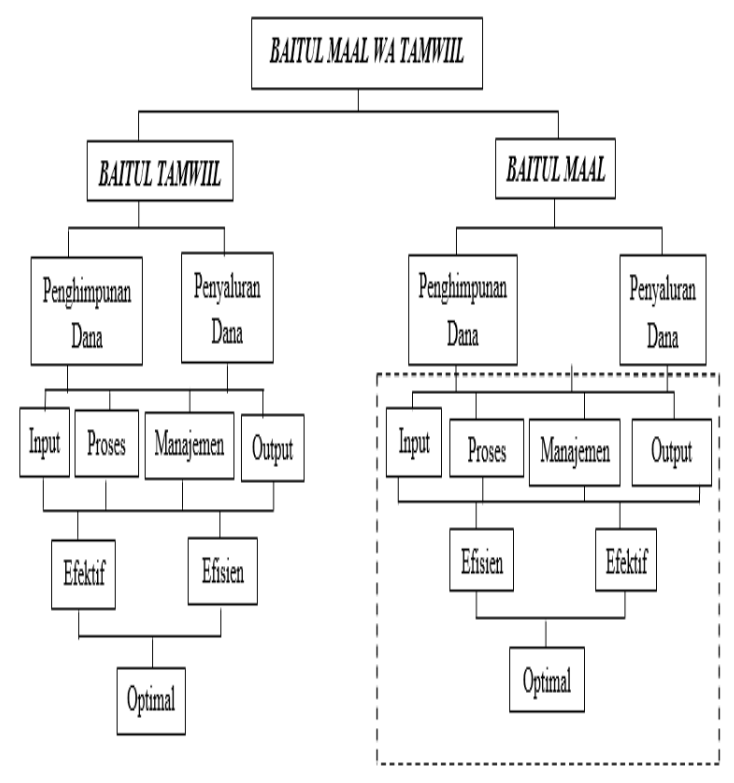

Gambar 1

Kerangka Berfikir

\section{G. Proposisi}

Penelitian ini didasarkan atas proposisi sebagai berikut, BMT adalah lembaga keuangan mikro Islam yang secara bersamaan menjalan dua fungsi yaitu maal dan tamwiil dengan optimal. Optimal dapat diukur dengan melihat bagaimana BMT mengelola sumber daya yang dengan efektif dan efisien.

\section{METODE PENELITIAN}

Penelitian ini menggunakan pendekatan kualitatif yaitu pendekatan penelitian yang digunakan untuk meneliti pada kondisi objek alamiah dimana peneliti adalah sebagai instrument kunci, teknik pengumpulan data dilakukan secara triangulasi (gabungan), analisis data bersifat induktif, dan hasil penelitian lebih menekankan makna dari pada generalisasi (Sugiyono,2011:8)
Metode yang digunakan adalah studi kasus menggunakan pendekatan kualitatif, dengan jenis penelaahan eksplanatoris yang berpedoman pada pernyataan "bagaimana" atau "mengapa" yang akan diarahkan pada serangkaian peristiwa yang bersifat temporer, yaitu dimana kecil peluang atau tak memiliki peluang sama sekali untk melakukan kontrol terhadap peristiwa (Yin 2013:13).

Ruang lingkup penelitian ini terbatas pada rumusan masalah mengapa fungsi sosial (baitul maal) pada baitul maal wa tamwil (BMT) kurang optimal dalam menjalankan kedua fungsinya yaitu fungsi bisnis (baitul tamwil) dan fungsi sosial (baitul maal). Jenis dan sumber data yang digunakan adalah data utama dan data penunjang. Data utama yang digunakan berupa wawancara pada key informan dan data penunjang berupa laporan keuangan dan laporan kegiatan sosial BMT Nurul Jannah di Gresik dan BMT Muda di Surabaya.

Teknik pengumpulan data penelitian ini menggunakan teknik wawancara partisipasi aktif dimana peneliti tidak terlibat langsung dengan kegiatan operasional BMT. Teknik yang kedua yaitu wawamcara dimana peneliti melakukan tanya jawab dengan key informan dalam hal ini adalah pimpinan dan manajer bagian maal BMT Nurul Jannah Gresik dan ketua BMT, pengelola $B M T$, pengawas BMT serta anggota BMT Muda Surabaya. Teknik yang terakhir 
adalah dokumentasi berupa data laporan keuangan dan laporan kegiatan sosial BMT.

Teknik validasi data yang digunakan adalah triangulasi sumber dengan menggabungkan hasil wawancara antar narasumber. Teknik validasi data yang kedua adalah triangulasi data yaitu menggabungkan data yang diperoleh dari beberapa narasumber. Unit analisis menurut Yin (2003 dalam Grunbaum, 2007) unit of analysis is identical with the case itself, dalam penelitian ini penelitiannya adalah fungsi Baitul Maal dalam lembaga keuangan mikro Islam. Teknik analisis penelitian ini menggunakan analisis domain yaitu gambaran umum BMT meliputi kinerja dan fungsi BMT. Teknik yang kedua yaitu analisis komponensial dengan membandingkan kinerja dan fungsi antara BMT Nurul Jannah Gresik dan BMT Muda Surabaya.

\section{HASIL PENELITIAN DAN PEMBAHASAN}

\section{A. Deskripsi Hasil Penelitian}

\section{Pengertian BMT}

BMT adalah lembaga kevangan mikro Islam yang pelaksanaannya berdasarkan ajaran syariah-syariah Islam. Lembaga ini menjalankan dua fungsi utama yang terdiri dari fungsi maal yaitu fungsi sosial, dan fungsi tamwil yaitu fungsi bisnis dengan pendapatan keuntungannya melalui sistem bagi hasil.

\section{Fungsi BMT}

BMT memiliki dua fungsi sesuai dengan kepanjangannya yaitu baitu tamwl yang berarti rumah pembiayaan atau bisnis dan baitu maal yang berarti rumah harta atau sosial. Kedua fungsi tersebut merupakan pembeda BMT dengan lembaga keuangan Islam lainnya. Fungsi sosial yang dilakukan BMT adalah penghimpunan dan penyaluran dana zakat, infaq, shodaqoh. Sedangkan fungsi bisnis yang dijalankan BMT adalah pembiayaan untuk masyarakat sekitar BMT.

\section{Kendala BMT}

Kendala merupakan hal yang pasti dimiliki setiap organisasi dalam menjalanjalankan usahanya. Kendala organisasi dapat menjadi penghambat untuk dapat berkembang. BMT memiliki kendala kurangnya SDM untuk dapat menghimpun dana baitul maal.

\section{Motivasi BMT}

Motivasi dapat didefinisikan
sebagai suatu hal yang dapat
menggerakkan organisasi untuk
mencapai tujuan. Motivasi yang
mendasari berdirinya BMT Muda adalah
keinginan untuk membentuk suatu
lembaga riset yang berorientasi pada
kemaslahatan umat disekitar BMT. Awal
mula berdirinya BMT Nurul Jannah adalah
bertujuan untuk dapat membantu
pedagang di sekitar masjid Nurul Jannah
agar dapat memperoleh pembiayaan
sebagai modal usahanya. Hal inilah dapat
disimpulkan bahwa motivasi BMT Nurul
Jannah didirikan memang lebih fokus
kepada motivasi bisnis.

\section{Fokus BMT}

Fokus disini merupakan implementasi dari motivasi BMT. Apabila 
motivasi BMT lebih kepada aspek bisnis maka fokus BMT tersebut tentu lebih perhatian pada kegiatan bisnisnya. Fokus BMT Muda masih pada bidang bisnisnya karena masih mengukuhkan pondasi sebagai BMT baru. Begitu juga dengan fokUs dari BMT Nurul Jannah, sama seperti BMT Muda yaitu yang bermotivasi sebagai lembaga yang orientasinya pada profit maka perhatian dari fokus kerja BMT yaitu lebih ke fungsi bisnisnya.

\section{Efektif dan Efisien BMT}

Kinerja ekonomi merupakan salah satu cara untuk dapat melihat apakah suatu organisasi dapat dikatakan efektif dan efisien. Semakin tinggi tingkat pertumbuhan kinerja ekonomi suatu organisasi maka semakin efektif dan efisien organisasi tersebut dalam mengelola sumber daya yang dimilikinya.

Berikut ini adalah lampiran tabel perbandingan asset, pemasukan dan penyaluran dana dari kegiatan maal, laporan kegitan maal dan tamwil pada BMT Nurul Janah dan BMT Muda.

\section{Tabel 1}

\section{Analisis Domain dan Komponensial}

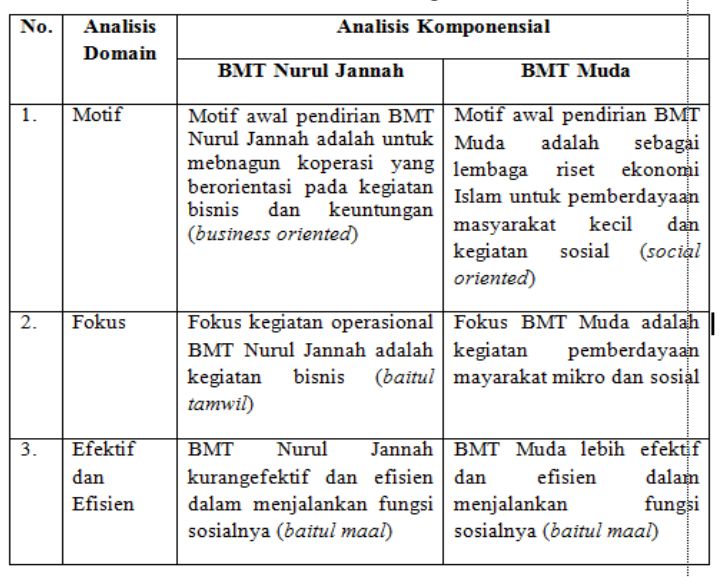

Sumber : Hasil Penelitian Diolah
Pada Tabel di atas dapat dijelaskan analisis mengenai keoptimalan fungsi baitul maal pada lembaga kevangan mikro Islam BMT disebabkan oleh lebih dominannya motivasi bisnis dari pendirian baitul maal wa tamwil (BMT) tersebut. Apabila motivasi dari BMT tersebut cenderung mengarah kepada aspek bisnis, maka tentu akan berdampak pada fokus perhatian atas rencana kerja di bidang tamwil lebih besar dibandingkan dengan fokus perhatian disisi maalnya.

\section{Pembahasan Motivasi BMT Nurul Jannah dan BMT Muda}

Menurut Stephen P. Robbins (Wibowo, 2013:378) motivasi merupakan proses yang menimbulkan adanya intensitas (intensity), arah (direction), dan usaha terus-menerus (persistance) yang dilakukan oleh individu menuju pencapaian tujuan. Jerald Greenberg dan Robert A. Baron (Wibowo, 2013:379) berpendapat bahwa motivasi merupakan serangkaian proses yang membangkitkan (arouse), mengarahkan (direct), dan menjaga (maintain) perilaku manusia menuju pada pencapaian tujuan.

Motivasi merupakan suatu energi di dalam diri seseorang yang mendorong, membangkitkan, mengarahkan, dan menjaga perilaku seseorang untuk dapat mencapai tujuan tertentu. Manusia sebagai hamba allah yang paling sempurna ditekankan untuk melakukan segala sesuatu dengan sebaik-baiknya dan berlomba-lomba dalam kebaika. Hal 
tersebut tercermin dalam surat Ar-Rahman ayat 33 sebagai berikut:

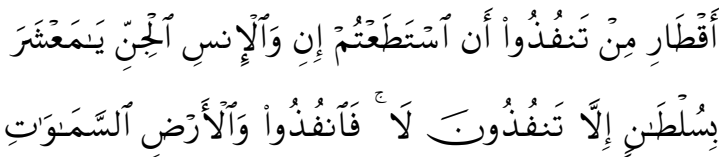
(표

Yâma'syaral jinni wal-insi inis tatha'tum an tanfudzû min aqthâris samâwâti walardli fanfudzû lâ tanfudzûna illâ bisulthân. Artinya: "Hai jama'ah jin dan manusia, jika kamu sanggup menembus (melintasi) penjuru langit dan bumi, Maka lintasilah, kamu tidak dapat menembusnya kecuali dengan kekuatan".

Surat Ar-Rahman di atas dijelaskan bahwa manusia hendaknya memotivasi dirinya untuk mencari karunia Allah dengan menggunakan kekuatan dari Allah. Kekuatan yang dimaksud adalah ilmu.

\section{Pembahasan Fokus BMT Nurul Jannah dan BMT MUDA}

Literatur manajemen strategik menunjukkan pengelompokan hasil yang maksimal dalam analisis SWOT organisasi terhadap saingan mereka. Organisasi yang berhasil adalah mereka yang memiliki kompetensi khusus dan berkelanjutan dari waktu ke waktu. Prahalad dan Hamel (dalam Beekun, 2006:28) mendefinisan inti kompetensi sebagai pembelajaran bersama di dalam organisasi, terutama bagaimana cara mengkoordinasi bermacam-macam skill (kemampuan) produksi dan menggabungkan bermacam-macam kemajuan teknologi. Organisasi harus mengenali kompetensi yang mana yang harus difokuskan kemudian meninggalkan pekerjaan yang mana relatif lemah dan tidak efektif, dan yang tidak selaras dengan visi dan misi organisasi tersebut.

\section{Pembahasan Efektif dan Efisien BMT} Nurul Jannah dan BMT MUDA

Efisien adalah tentang internal organisasi dalam menjalankan tugasnya. Efisiensi dapat diukur dengan melihat input ataupun output dari organisasi. Jika organisasi dapat menggunakan sumber dayanya dengan lebih sedikit dari pada outputnya maka organisasi tersebut dapat dikatakan efisien. Sedangkan efektifitas adalah tingkat dimana organisasi mampu menyadari tujuannya. Efektifitas digunakan untuk mengukur sejauh mana tujuan-tujuan yang ada di organisasi telah tercapai (Griffin, 2011: 5-6).

Efektif dan efisien dalam Islam tercermin pada ihsan dan itqan dalam bekerja. Ihsan adalah optimalisasi dalam kebaikan atau kebaikan apapun yang dilakukan seseorang harus optimal dalam persiapan dan pelaksanaannya. Itqan adalah kesungguhan dan kemantapan dalam melaksanakan suatu tugas, sehingga yang dikerjakan maksimal dan selesai dengan baik.

Melakukan pekerjaan dengan itqan tertulis pada Al-Quran surat An-Maml ayat 88:

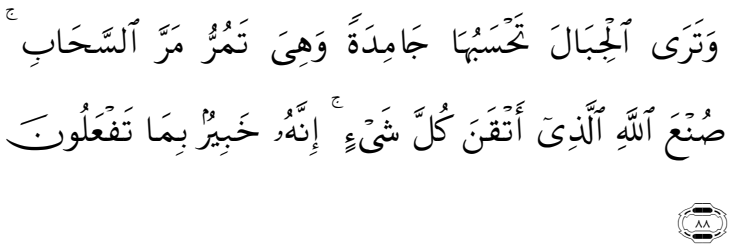

Watarāl jibāla tahsabuhā jāmidatan wahiya tamurru marrasahābi śu'allahilla żī 
'anqana kulla syai'in 'innahu khabīrun bimā taf"alūna.

Artinya: Dan kamu Lihat gunung-gunung itu, kamu sangka Dia tetap di tempatnya, Padahal ia berjalan sebagai jalannya awan. (Begitulah) perbuatan Allah yang membuat dengan kokoh tiap-tiap sesuatu; Sesungguhnya Allah Maha mengetahui apa yang kamu kerjakan.

Ayat tersebut menjelaskan bahwa segala sesuatu harus diatur dan dibuat dengan indah untuk dapat memperoleh hasil yang sempurna atau maksimal. Ayat lain menjelaskan bahwa manusia harus bekerja dengan insan untuk dapat menghasilkan kinerja yang optimal.

\section{v. SIMPULAN}

Berdasarkan

penjelasan

pembahasan hasil analisis pada bab empat, bahwa penelitian dengan judul "Analisis Keoptimalan Fungsi Baitul Maal Pada Lembaga Keuangan Mikro Islam (Studi Kasus Pada BMT Nurul Jannah di Gresik dan BMT Muda di Surabaya) " dapat disimpulkan fungsi baitul maal pada lembaga keuangan mikro Islam kurang optimal dikarenakan motivasi pendirian BMT tersebut. Apabila motivasi bisnis yang mendasari maka fokus BMT lebih pada aktivitas bisnis, jika motivasi sosial yang mendasari didirikannya maka fokus BMT tersebut pada aktivitas sosial.

\section{DAFTAR REFERENSI}

Abdullah, Ma'ruf. 2012. Manajemen Berbasis Syariah. Yogyakarta: Aswaja Pressindo.
Agoes, Sukrisno. 2013. Auditing: Petunjuk Pemeriksaan Akuntan oleh Akuntan Publik. Jakarta: Salemba Empat.

Al-Qur'an Al-Karim. Terjemahan. Departemen Agama Islam

Beekun, Rafik Issa. 2006. Strategic Planning and Implementation For Islamic Organizations. USA: The International Institute of Islamic Thought

Buchari, Nur S. 2009. Koperasi Syariah. Sidoarjo: Masmedia Buana Pustaka

Daft, Richard L. 2001. Essential of Organozation Theory \& Design. Edisi Kedua. South-Western: Thomson Learning

Diola, Alfa. 2011. Peran Baitul Maal Wat Tamwil Dalam Peningkatan Kesejahteraan Anggota Pada BMT-UGT Sidogiri di Kota Surabaya. Skripsi tidak diterbitkan. Surabaya: Fakultas Ekonomi dan Bisnis Universitas Airlangga.

Griffin, Ricky W. 2013. Management Principles and Practice. Edisi Kesebelas. South-Western: Cengage Learning

Grunbaum, Niels N. 2007. Identification of Ambiguity in the Case Study Research Typology: What is a Unit of Analisis.Qualitative Market Research: An International Journal Vol. 10 No.1 pp 79-97. DOI $10.1108 / 13522750710720413$ 
Handoko, T. Hani. 2003. Manajemen. Cetakan Kedelapanbelas. BPFEYogyakarta: Yogyakarta.

Huda, Nurul, Achmad aliyadin, Agus Suprayogi, dkk. 2012. Keuangan Publik Syariah: Pendekatran Teoritis dan sejarah. Jakarta: Kencana Prenada Media Group

IImi, Makhalul. 2002. Teori Dan Praktek Mikro Keuangan Syariah: Beberapa Permasalahan dan Alternatif Solusi. Yogyakarta: UII Press

Karim, Adiwarman Azwar. 2010. Sejarah Pemikiran Ekonomi Islam. Edisi Ketiga. Jakarta: RajaGrafindo Persada

Kurniawan, Agung. 2005. Transformasi Pelayanan Publik. Yogyakarta: Pembaruan.

Muhammad. 2007. Lembaga Ekonomi Syariah. Yogyakarta: Graha IImu Nanda, Aditya Surya Nanda. 2012. Keseimbangan Fungsi Baitul Maal Dan Fungsi Baitul Tamwil Pada Lembaga Keuangan Mikro Islam
Di Surabaya Dan Sekitarnya. Skripsi tidak diterbitkan. Surabaya: Fakultas Ekonomi Dan Bisnis Universitas Airlangga

Ridwan, Muhammad. 2004. Manajemen Baitul Maal Wat Tamwil (BMT). Yogyakarta: UII Press

Rivai, Veithzal. 2009. Islamic Human Capital Dari Teori Ke PraktikManajemen Sumber Daya Islami. Edisi Pertama. Jakarta: Rajawali Pers.

Robbins, Stephen P. 2003. Organizational Behaviour. Teenth Edition. New Jersey: Prentice.

Sudarsono, Heri. 2012. Bank dan Lembaga Kevangan Syariah: Deskripsi dan Ilustrasi. Edisi Ketiga. Yogyakarta: Ekonisia UII Yogyakarta

Yin. Prof. Dr. Robert K. 2013. Study Kasus Desain \& Metode.Cetakan Kedua Belas. Edisi Pertama. Jakarta: RajaGrafindo Persada (Rajawali). 